\title{
An Empirical Study on the Mechanism of Five-Entry Education to College Students' Innovation-Entrepreneurship Intention
}

\author{
Banghong Kuang ${ }^{1, a}$, Luxia Yi ${ }^{1, b}$ and Yucong You ${ }^{1, c}$ * \\ ${ }^{1}$ Guangzhou College of Business and Technology, Guangzhou, China \\ astoneyyc@163.com, ${ }^{\mathrm{b}} 61070262 @ q q . c o m,{ }^{\mathrm{c}}$ stoneyyc@163.com*
}

Keywords: College Education; Five-Entry Education; Empirical Study; Innovation-Entrepreneurship

\begin{abstract}
This paper explains and demonstrates how five-entry education philosophy functions as a mechanism to cultivate the innovation-entrepreneurship intention of college students. From the perspective of innovation and entrepreneurship, this paper, based on the theory of planned behavior, examines the impact of the five-entry education and teaching factors on the innovation and entrepreneurship of college students. The present study analyzes the relevant hypotheses by means of factor analysis and multiple regression analysis, which are based on 7510 valid questionnaires from third and fourth grade college students. The main findings and conclusions of this study show that five-entry education is positively related to the entrepreneurial intention of college students. Moreover, five-entry education has a significant positive effect on the innovation and entrepreneurship intention of college students by means of innovative teaching factors.
\end{abstract}

\section{Introduction}

Innovation and entrepreneurial activity is the foundation and core of social and economic development, serving as the bridge of transforming science and technology into productive forces. Innovation and entrepreneurial activity has increasingly become an important driving force for national economic development. Nowadays, numerous countries are undertaking a strategy of building an innovative country. In the process of cultivating the national innovation system and creating the entrepreneurial environment, innovation and entrepreneurship education should be carried out as the top priority to serve innovative country strategy. Only through the work of innovation and entrepreneurship education, innovative and entrepreneurial talents can be cultivated and fostered, so as to promote innovation and entrepreneurship activities throughout a particular country. In this context, innovation and entrepreneurship education has drawn unprecedented attention. How to carry out innovation and entrepreneurship education and how to cultivate innovative and entrepreneurial talents have become a common concern of the authorities, education and academia. Guangzhou College of Business and Technology beholds the "Five-entry" education teaching philosophy, which is an important bridge of college education and the innovative strategy, namely, by means of encouraging and inspiring college students to enter into the classroom, into the library, into the experimental training room, into the stadium and into society. By the "Five-entry" education practicing activity being conducted, college students' overall qualification can be strengthened from various aspects; the purpose of it is to foster and cultivate the qualified innovative and entrepreneurial spirits of college students through training and development, morally, intellectually and physically. This article possesses practical significance for universities and colleges to cultivate the innovative and entrepreneurial talents for the society.

\section{Literature Review}

Lumpkin (1996) claimed that the nature of entrepreneurship is not limited to the limitations of current resources but to identify and exploit opportunities, including the creation of new businesses or the development of new business activities within existing enterprises. Many foreign scholars have pointed out that entrepreneurship is entrepreneurial innovation where entrepreneurs and opportunities 
are combined to create value (Sirmon, 2003); some scholars have pointed out that entrepreneurship and general management is not mutually exclusive, to a certain extent, they are overlapping with each other, entrepreneurship is more of an innovation-driven activity. As for innovation-entrepreneurial education in universities, Mwasalwiba (2010) pointed out that university innovation-entrepreneurship education should pay attention to students' attitudes, values, intentions and personal skills. Porter (2010)claimed that innovation-entrepreneurship education is to educate individuals with a series of basic skills and related knowledge of education, regardless of whether the individual is to choose employment or self-entrepreneurship, with these capabilities can they make a unique, innovative and creative contribution at work (Bridge, 2010; Hejiay, 2010; Curavic, 2011). Some scholars have pointed out the innovation-entrepreneurial education goal as: training students to create new businesses and manage new business skills (Gerald, 1988; Kontio, 2010; Robert, 2010;). Rizza (2011) argues that innovation-entrepreneurship education has been characterized as the most significant achievement in modern higher education systems. Kuang (2015) proposed that through the "five-entry" education, development of college innovation-entrepreneurship education can be effectively promoted. From the perspective of large data mining, You \& Yi (2016) studies the bridge and link between the transformation of science and technology into productive forces in the education of higher education in terms of innovation-entrepreneurship.

\section{Model Construction}

Based on previous research results, the core concepts related to this section are defined. This paper argues that college students innovation-entrepreneurial intention refers to the conscious mental state of college students and thus innovation-entrepreneurial education is to cultivate students' entrepreneurial awareness and innovative thinking. According to the theory of Planned Behavior, the intention of the individual is the key to explain why he completes a particular act. Based on this, this present study came up with a question: what is the effect of the university's innovation-entrepreneurial education on the innovation-entrepreneurial intention of college students? We identify the university's innovation-entrepreneurial education with the media factor of five-entry education as the pre-influencing factors, and thus the research question has come to a specific one: what is the mechanism of the university's innovation-entrepreneurial education onto the innovation-entrepreneurial intention of college students?

Innovation-entrepreneurship education is a combination of theoretical knowledge and skills development, based on these five hypotheses are provided as follows.

Table 1 Hypothesis of the Study

\begin{tabular}{|c|l|}
\hline H1. & $\begin{array}{l}\text { An innovation-entrepreneurship classroom teaching (entry into the classroom) is } \\
\text { positively correlated will the innovation-entrepreneurship intention of college students. }\end{array}$ \\
\hline H2. & $\begin{array}{l}\text { An innovation-entrepreneurship literature reading (entry into the library) is positively } \\
\text { correlated will the innovation-entrepreneurship intention of college students. }\end{array}$ \\
\hline H3. & $\begin{array}{l}\text { An innovation-entrepreneurship drill (entry into the experimental room) is positively } \\
\text { correlated will the innovation-entrepreneurship intention of college students. }\end{array}$ \\
\hline H4. & $\begin{array}{l}\text { Students' physical condition (entry into the stadium) is positively correlated will the } \\
\text { innovation-entrepreneurship intention of college students. }\end{array}$ \\
\hline H5. & $\begin{array}{l}\text { An innovation-entrepreneurship social ability (entry into the society) is positively } \\
\text { correlated will the innovation-entrepreneurship intention of college students. }\end{array}$ \\
\hline
\end{tabular}

The independent variables in the research model are the logical factors of college students' innovation-entrepreneurship in the teaching of "five-entry" in the university. This is the core of this study to answer the above research question. This study attempts to construct an indirect effect model. The core dependent variable of this study is the innovation-entrepreneurship intention of college students, and other variables revolve around logical reasoning. Based on the perspective of innovation-entrepreneurship education, the influential factors of college students' innovation-entrepreneurship intention - the school teaching factor is the independent variable of this 
study. This paper uses a single item as a projection variable to measure the dimensions of the school teaching factors. In particular, this paper divides the school teaching factors in the university's innovation-entrepreneurship education into five dimensions: into the classroom, into the library, into the experimental training room, into the stadium and into the society, respectively, corresponding to the indirect effect projection variables: classroom teaching, literature reading, simulation training, physical fitness, and social practice. Based on previous research results, this study intends to introduce control variables from the school level and the student level. Specifically, school's geographical location, school type, students' gender, grade are treated as controlled variables.
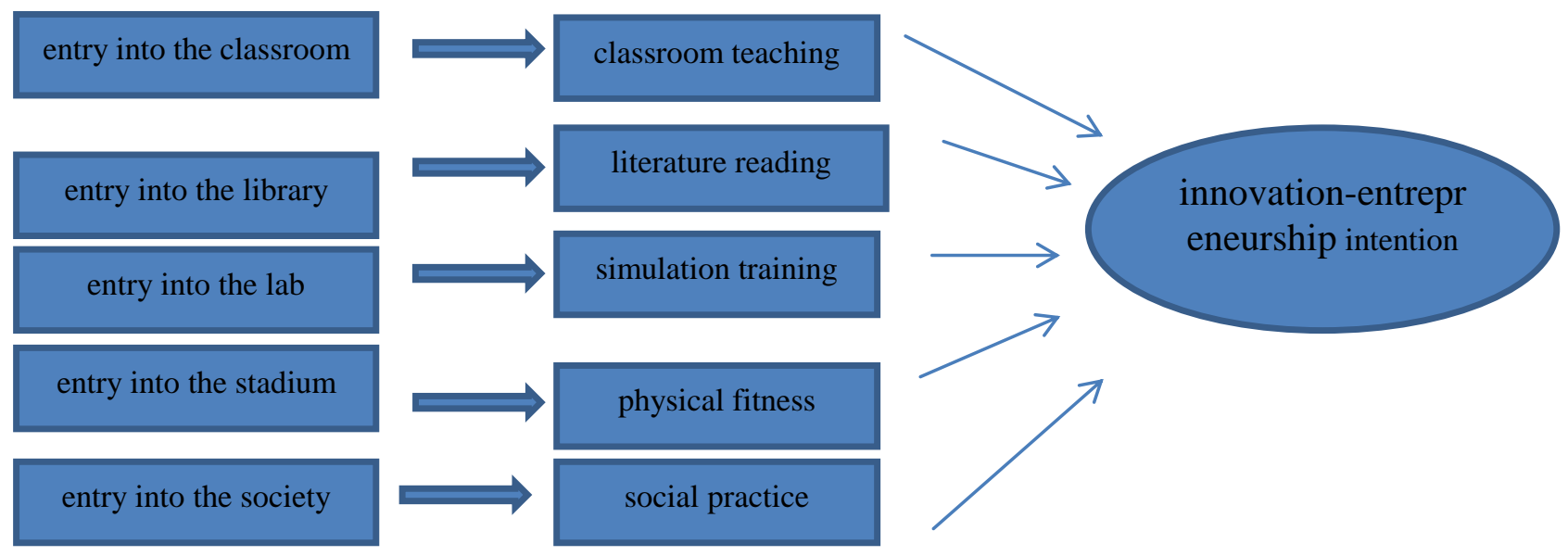

Figure 1. Theoretical Model

The research data used in this study are based on the questionnaire survey. Questionnaires were performed by non-probabilistic sampling methods. The research data used in this study are: senior students of GCBT, namely: the second year and third year college students. Questionnaires were distributed to the target students and collected on site by the researcher.

\section{Results and Discussion}

We applied the statistical software SPSS16.0 to this study, and based on the multiple regression analysis method, the related hypotheses were statistically tested. Table 2 lists the results of the multiple linear regression models of five-entry factors and college students' intention of innovation-entrepreneurship .

Table 2 Results of multiple linear regression models of five-entry factors

\begin{tabular}{c|c}
\hline Variable & Dependent Variable \\
\hline Controlled variable & 0.0231 \\
\hline Variables & \\
\hline Entry into the classroom & $0.057^{* * *}$ \\
\hline Entry into the library & $0.061^{* * *}$ \\
\hline Entry into the experimental room & $0.067^{* * *}$ \\
\hline Entry into the stadium & $0.042^{* *}$ \\
\hline Entry into the society & $0.040^{* *}$ \\
\hline R square & 0.069 \\
\hline Adjusted R square & 0.043 \\
\hline VIF & $8.598^{* * *}$ \\
\hline N,df & 7510,17 \\
\hline DW & 1.985
\end{tabular}

Note: *indicates $\mathrm{P}<10 \%$; ** indicates $\mathrm{P}<5 \%$; *** indicates $\mathrm{P}<1 \%$

The variance expansion coefficient VIF $<10$ of the model shows that there is no multi-collinearity problem between the control variables of the model. The model DW $=1.985$, indicating that there is no autocorrelation between the residual terms of the model. From the model in the table, we can see that "Entry into the classroom" has a significant positive predictive effect on the 
"innovation-entreprenuership" intention of college students $(\beta=0.057 * * *) ; “$ Entry into the experimental room" has a significant effect on the intention; the hypothesis 2 is validated by the predictive effect $(\beta=0.061 * * *)$, and the "entry into experimental training room" has a significant positive predictive effect on the intention $(\beta=0.067 * * *) ;(\beta=0.042 * *)$ indiccates thta hypothesis 4 is validated by the "Entry into the stadium" on the intention. There is a significant positive predictive effect on the intention of college students with "Entry into the society" ( $(=0.040 * *)$, assuming that 5 is verified. In particular, the main effect relationship between five-entry factors and college students' "innovation-entreprenuership" intention is verified by empirical data. And thus all the hypotheses were verified eventually.

\section{Summary}

The data and empirical tests were conducted from the effective questionnaires of the third and fourth year students of GCBT. The main conclusions and findings are summarized as follows:

Those college students who participate in the five-entry education more frequently, their intention of entreprenuership is most likely to be enhanced accordingly. This find is consistent with what the theory of planned behavior claim that an individual behavioral behavior can predict his intention and finally explain the occurrence of actual behavior. Accordingly, the behavioral innovation-entreprenuership attitude of individual reflects his desire for a innovation-entreprenuership behavior. This study found that five-entry education acts as a bridge of linking the skills training and theoretical cultivation to the enhancement of their intention. Furthermore, these research results also show that the five-entry education is, in essence, oriented to fostering different professional values of students with targeted teaching, and thus the five-entry mechanism functions to develop the potential innovative sense of the students., which potentially and profoundly influence students' entreprenuership in the future..

\section{Acknowledgements}

This work was financially supported by Guangdong Province: The Construction of Key Disciplines of International Trade; Guangdong Province Private Education Base Study.

\section{References}

[1] Ajzen I,Fishbein M. The influence of attitudes on behavior. [M]Mahwah,NJ:Erlbaum,2005

[2] Bird B. Implementing entrepreneurial ideas: The case for intention. [J] Academy of Management Review, 1998

[3] Gerald E.H. Variations in University Entrepreneurship Education. [J] Journal of Business Venturing, 1998

[4] Kontio J. Inspiring the inner entrepreneur in students-a case study of entrepreneurship studies in TUAS. [J] Ecole Polytechnique, Montreal, 2010

[5] Raposo M, do Paco A. Entrepreneurship Education: relationship between education and entrepreneur activity. [J] Psicothema,2011

[6] Kuang Banghong. On the Exploration and Practice of the Five Entries from Guangzhou College of Business and Technology .[M] Guangdong Higher Education Press, 2015

[7] You Yu-cong, Yi Luxia. An Technological innovation Research on Education Statistical Work in In Big Data Era [C] . Proceedings of 2016 2nd International Conference on Education and Management Science (ICEMS 2016) 